\title{
PERSPECTIVE
}

\section{CIF/IFC DIRECTIONS 2000}

The dawning of another new century gives us a time to reflect on the past 100 years and then look forward. Each of us has our own personal vision of how the forestry profession will respond to societal needs and challenges. Often cited is the definition of forestry as an art and a science of attaining desired forest conditions and sustainable benefits. The forestry profession has a proud history of achievement in Canada. The many excellent presentations at the CIF/IFC conference in Banff illustrated that fact admirably. All of the presenters, with their own vision, and expertise, gave a personal glimpse into the future. In summary, they saw many challenges, but more importantly saw great opportunities. Technological breakthroughs and knowledge transfer are two of the biggest trump cards to be played in the coming years. The dedication of many researchers and practitioners will continue to find solutions through science and technology for many of our perplexing issues. Yet, it will be through the growth in knowledge and understanding within society that we will reap the greatest gains in the advancement of forestry in the $21^{\text {st }}$ century.

So, how will CIF/IFC respond? I believe that your Board of Directors has set into motion the kind of strategies that will make a difference. Members of the Institute have one clear purpose...to communicate their knowledge to enhance and sustain forest resources for the benefit of all. Towards this goal, members in

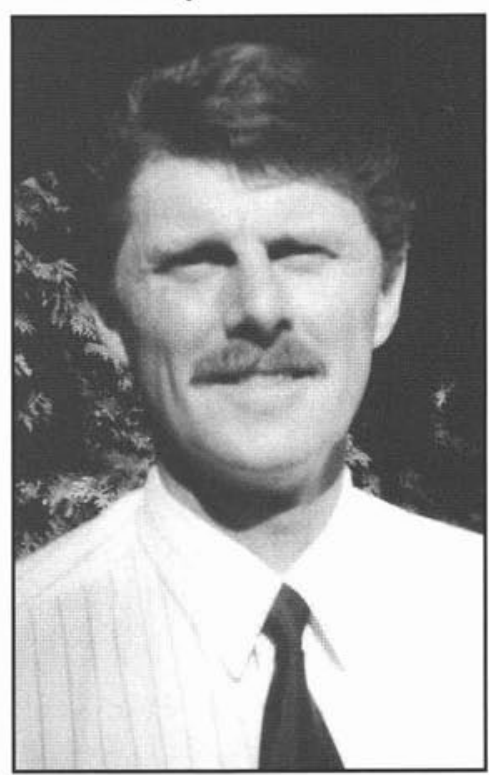

L'aube du nouveau siècle qui approche constitue un moment idéal pour analyser les cent dernières années et pour étudier l'avenir. Chacun de nous avons notre propre vision de comment la profession de la foresterie pourra répondre aux besoins et aux défis de la société. On cite souvent la définition de la foresterie comme étant un art et une science permettant d'atteindre les conditions forestières désirées et des bénéfices durables. La profession de la foresterie détient un fier historique de réalisations au Canada. Les nombreuses et excellentes présentations de la conférence de l'Institut à Banff ont illustré ce fait de façon admirable. Chacun des conférenciers, selon sa propre vision et expertise, a partagé un aperçu personnel de l'avenir. En résumé, ils ont envisagé plusieurs défis, mais plus important, ils ont entrevu de grandes possibilités. Les percés technologiques et le transfert de connaissance constituent deux des plus importants atouts à jouer au cours des prochaines années. Le dévouement de plusieurs chercheurs et praticiens permettra de poursuivre la recherche de solutions par le biais de la science et de la technologie dans le cas de plusieurs de nos questions primordiales. De plus, ce sera par l'entremise de l'accroissement de la connaissance et de la compréhension au sein même de la Bruce A. Ferguson R.P.F. President société que nous récolterons le plus important progrès dans l'avancement de la foresterie au $21^{\mathrm{e}}$ siècle.

Alors, qu'est-ce que l'Institut peut répondre à cela ? Je crois que le Conseil d'administration a mis en marche le genre de stratégie qui fera la différence. Les membres de l'Institut ont un objectif précis... communiquer leurs connaissances pour améliorer et maintenir les ressources forestières pour le bénéfice de tous. Pour atteindre cet objectif, les membres de plusieurs groupes de travail résumeront nos valeurs et nos croyances sous forme d'un ensemble global de politiques forestières et élaborerons des prises de positions concises sur les questions d'actualité. Le Conseil a adopté les quatorze priorités en matière de politiques suivantes, pour qu'elles soient élaborées, révisées et disséminées.

Elles sont : L'importance des forêts; Le développement durable; L'aménagement forestier durable; La protection des forêts; L'inventaires des ressources forestières; La recherche forestière; La participation du public; Les investissements forestiers; Les fonds forestiers; Les espèces indigènes; La formation des professionnels; Les responsabilités professionnelles; La certification forestière; et Les questions et les relations internationales. Au cours des deux ou trois prochaines années, ces énoncés de politique seront élaborés et adoptés. Chaque membre devrait faire connaître ses commentaires de telle sorte que le document final contenant les politiques reflète nos valeurs et croyances collectives. $\$ \mathbf{8 8 7}$ 
Editorial fact, in return for receiving a title or a certificate that provides official recognition and that opens markets (employment or commerce), an individual or a group accepts to restrict themselves to recognized criteria, thus assuring the public or the client of the quality they require. In one case, the issue is the protection of the public and of its collective forest patrimony, and in the other, the credibility of the company in the marketplace. In both cases, continuous improvement is the key to success in ensuring the sustainability of this recognition.

At this stage, it appears important to me that the rigour of the two processes be examined with respect to follow-up provided for continuous improvement. It is evident that certification, through its recurrent audits, puts forward a rigorous periodic verification. The professional orders and associations also provide validation steps and many opportunities for continuous improvement. It would certainly be apropos for these organizations to be prompted by the methodology and rigour of the certification processes when updating their professional training mechanisms. For example, professional inspection, as it applies to the Ordre des ingénieurs forestiers du Québec, is more and more being oriented to an audit of a professional's practices. Continuous education follow-up of professional foresters is already the object of discussions in several provinces, and it is important to continue in this direction. The Order is continuously working to improve these two aspects.

The progressive implementation of the certification of forestry practices provides us with avenues and models which we must use. Professionals would only be better prepared for this new reality.

\section{.... and recognition to be confirmed}

In parallel, the quality of services provided by professional foresters to society, and the mechanisms that the professional orders and associations have developed to ensure the protection of the public, must be recognized in the certification standards. These must integrate a direct reference to the expertise of professional foresters, to the laws and regulations to which they are subject, particularly in the matter of a professional code of conduct and ethics, and to the responsibilities that are incumbent on them in terms of protecting the public. This should be officially recognized as an inescapable element in any certification procedure. The CSA standard already provides elements of this.

On the other hand, the eligibility criteria of the auditors, which already refer to professional competency, should be better linked to those of the orders and associations to ensure a coherent process.

In the current dynamic, and in light of the numerous debates that are on-going across the country, it is up to professional foresters and their orders and associations to make their competencies better known and recognized. These must of course rest on a solid basic education, but also and especially on a great capacity to keep their knowledge current and to demonstrate innovation in their daily practice. The public's confidence in professional foresters will be based mainly on the implementation of creative practices that are respectful of different values, as well as on a rigorous accreditation process. The certification standards should motivate us in this regard.

Perspective We must be seen to be heard and I challenge every member to get out in the public eye and demonstrate what it means to be a forestry professional.
Éditorial rigoureux. Les ordres et associations professionnelles proposent également des étapes de validation et de multiples opportunités d'amélioration continue. Il serait par ailleurs à propos que ces organismes s'inspirent de la méthodologie et de la rigueur des processus de certification dans la mise à jour de leurs mécanismes d'encadrement professionnel. Par exemple, l'inspection professionnelle, comme elle s'applique à l'Ordre des ingénieurs forestiers du Québec, s'oriente de plus en plus à une forme d'audit des pratiques d'un professionnel. Le suivi de la formation continue des forestiers professionnels fait déjà l'objet de discussions dans plusieurs provinces et il est important de poursuivre dans cette veine. À l'Ordre, nous travaillons continuellement à l'amélioration de ces deux volets.

L'implantation progressive de la certification des pratiques forestières nous donne des pistes et des modèles dont nous devrions nous inspirer. Les professionnels ne seraient que mieux préparés à cette nouvelle réalité.

\section{... et une reconnaissance à confirmer}

En parallèle, la qualité des services rendus par les forestiers professionnels à la population et les mécanismes que les ordres et les associations professionnels ont développés pour assurer la protection du public doivent trouver leur reconnaissance dans les normes de certification. Celles-ci doivent intégrer une référence directe à l'expertise des professionnels forestiers, aux lois et règlements auxquels ils sont assujettis, particulièrement en matière de déontologie et d'éthique, et aux responsabilités qui leur incombent en termes de protection du public. Le tout devrait officiellement être reconnu comme un élément incontournable dans toute démarche de certification. La norme de la CSA fournit déjà des éléments de contenu à ce chapitre. D'autre part, les critères d'éligibilité des auditeurs, qui réfèrent déjà aux compétences des professionnels, devraient être mieux arrimés à ceux des ordres et associations pour assurer la cohérence du processus.

Dans la dynamique actuelle et à la lumière des nombreux débats qui ont cours à travers le pays, il revient aux forestiers professionnels et à leurs ordres et associations de mieux faire connaître et reconnaître leurs compétences. Celles-ci doivent s'appuyer sur une solide formation de base certes, mais également et surtout sur une capacité importante de mettre leurs connaissances à jour et d'innover dans leur pratique au quotidien. La confiance du public envers les forestiers professionnels reposera principalement sur la mise en place de pratiques novatrices, respectueuses des différentes valeurs, de même que sur un processus d'accréditation rigoureux. Les normes de certification devraient nous inspirer à ce chapitre.

Perspective Cela aura une valeur incommensurable dans notre quête de dialogue plus ouvert avec les peuples autochtones du Canada. Nous devons rechercher les opportunités pour partager nos connaissances et de développer une compréhension approfondie de nos forêts, et de travailler ensemble vers l'atteinte à long terme de l'aménagement forestier durable pour les générations à venir. Cela constitue l'essentiel de la thématique annuelle de l'Institut pour 1999-2000.

Nous devons être vus pour être entendus et $\mathrm{j}$ 'incite tous les membres à saisir toute opportunité sur la scène publique pour démontrer ce que cela signifie d'être un professionnel de la foresterie. 